\title{
Raillietiella mottae (Pentastomida: Raillietiellidae) infecting Ameiva ameiva (Squamata: Teiidae) in Araripe Plateau, Northeast Brazil
}

\author{
E. G. Silva ${ }^{a}$, M. E. P. Santos ${ }^{b}$, S. V. Brito ${ }^{c}$,W. O. Almeida ${ }^{b}$ and S. C. Ribeiro Ald $^{b}$

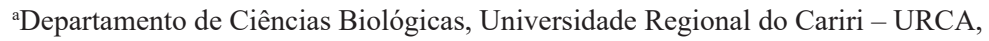 \\ Rua Cel. Antônio Luiz, 1161, Campus do Pimenta, CEP 63105-000, Crato, CE, Brasil \\ 'Programa de Pós-graduação em Bioprospecção Molecular, Universidade Regional do Cariri - URCA, \\ Rua Cel. Antônio Luiz, 1161, Campus do Pimenta, CEP 63105-000, Crato, CE, Brasil \\ ${ }^{c}$ Centro de Ciências Agrárias e Ambientais, Universidade Federal do Maranhão - UFMA, \\ Boa Vista, CEP 65500-000, Chapadinha, MA, Brasil \\ 'Instituto de Formação de Educadores - IFE, Universidade Federal do Cariri - UFCA, \\ Rua Olegário Emílio de Araújo, s/n, Campus Brejo Santo, CEP 63260-000, Brejo Santo, CE, Brasil \\ *e-mail: ribeiroherpeto@gmail.com
}

Received: April 16, 2017 - Accepted: July 25, 2017 - Distributed: February 28, 2019

\begin{abstract}
We investigated the infection by pulmonary parasites in the lizard Ameiva ameiva (Teiidae) inhabiting the Environmental Protection Area of Araripe (APA-Araripe). A total of 45 specimens were collected in three areas between the cities of Várzea Alegre and Barbalha. A Pentastomid species (Raillietiella mottae) was parasitizing (nine specimens) a male of A. ameiva with a prevalence of $2.22 \%$ considering all lizards collected in the region and prevalence of $50 \%$ considering only rainforest environment. The Pentastomids infection rates shown in this study are similar to data found for infections of other insectivorous lizards. Raillietiella mottae is considered a generalist parasite, which uses insects as intermediate hosts. The results of this study represent the first record of a Pentastomid infecting this species of lizard in South America.
\end{abstract}

Keywords: infection, neotropical, parasites, lizard.

\section{Raillietiella mottae (Pentastomida: Raillietiellidae) infectando Ameiva ameiva (Squamata: Teiidae) na Chapada do Araripe, Nordeste, Brasil}

\section{Resumo}

Neste estudo investigamos a infecção por parasitas pulmonares no lagarto teí́deo Ameiva ameiva (Teiidae) habitando a Área de Proteção Ambiental do Araripe - APA Araripe. Um total de 45 espécimes foram coletados em três áreas entre os municípios de Várzea Alegre e Barbalha. Uma espécie de pentastomida (Raillietiella mottae) estava parasitando (nove espécimes) um macho de $A$. ameiva com uma prevalência de $2,22 \%$, considerando todos os lagartos da região, e uma prevalência de $50 \%$ considerando apenas a floresta úmida. A taxa de infecção por pentastomídeos demonstrado no presente estudo é semelhante aos dados de infecção encontrados para outros lagartos insetívoros. Raillietiella mottae é considerado um parasita generalista, que usa insetos como hospedeiros intermediários. O resultado do presente estudo representa o primeiro registro de um pentastomídeo infectando lagartos do gênero Ameiva na América do Sul.

Palavras-chave: infecção, neotropical, parasita, lagarto.

\section{Introduction}

Parasites are important regulators of animal populations, affecting fertility, dietary habits, and other aspects of the natural history of their hosts (Marcogliese, 2004) Furthermore, the relationship between parasite and host is an important parameter for the study of biological communities (Rocha et al., 2000), operating even in the evolution of their hosts (Phillips et al., 2010).
Pentastomids are parasites of the respiratory tract of vertebrates, especially reptiles (Riley, 1986), with 144 species currently described (Christoffersen and Assis, 2013). The understanding of the biology of these parasites is important to assimilate the mechanisms of infection and identify conservation strategies of the host ex situ (Klingenberg, 1993; Marcogliese, 2004), and to 
understand how the parasites are involved in regulating the population of their hosts.

Raillietiella Vaney \& Sambon, 1910 is one of the few groups of Pentastomids that infect the respiratory tract of amphisbaenids, lizards and snakes recorded in South America (Almeida et al., 2008d). Studies involving pentastomid infection in lizards in the Neotropics were recorded, mostly in Brazil: Mabuya agilis Raddi, 1823 infected larvae Raillietiella sp. (Vrcibradic et al., 2002), Cnemidophorus abaetensis Dias, Rocha and Vrcibradic, 2002 and C. ocellifer (Spix, 1825) parasitized by Raillietiella aff. furcocerca (Dias et al., 2005) and Micrablepharus maximiliani Reinhardt and Lütken, 1862 parasitized by R. mottae Almeida, Freire and Lopes (Almeida et al., 2009), all in restinga environments; Trachylepis atlantica (Schmidt, 1945) infected by R. freitasi (Motta and Gomes, 1968), in Fernando de Noronha Island, Pernambuco state. On the domain of Caatinga, Northeast Brazil, R. mottae and R. frenata Ali, Riley and Self, 1981 were found parasitizing Hemidactylus mabouia (Moreau de Jonnès, 1818) in human habitations (Anjos et al., 2007; Almeida et al., 2008c), the remaining records include only $R$. mottae infecting: Tropidurus hispidus (Spix, 1825) (Almeida et al., 2008a, b, 2009; Brito et al., 2014), T. semitaeniatus (Spix, 1825) (Almeida et al., 2008b, 2009; Brito et al., 2014), Phyllopezus periosus Rodrigues, 1986 (Almeida et al., 2008b; Brito et al., 2014), P. pollicaris (Spix, 1825) (Almeida et al., 2008b; Sousa et al., 2010, 2014; Brito et al., 2014), M. arajara Rebouças-Spieker, 1981 (Ribeiro et al., 2012a), and H. mabouia (Sousa et al., 2014).

Ameiva ameiva (Linnaeus, 1758) it is a medium-sized lizard in relation to other terrestrial Neotropical lizards (Vitt and Colli, 1994), diurnal, inhabiting preferably open areas, ecotones and degraded environments (Vitt and Colli, 1994; Vitt, 1995; Ribeiro et al., 2012b). In all pulmonary parasitology work carried out with lizards, the gekkota clade is the species with the highest rates of pentastomid infection (Almeida et al., 2008a, b, c, 2009; Brito et al., 2014; Ribeiro et al., 2012a; Sousa et al., 2014). Thus, investigative studies with other families of lizards, such as Teiidae, offer the opportunity to identify patterns of pulmonary infection involving different groups of lizards. In the present study, we investigated the pentastomid infection in lizard $A$. ameiva in an area where Pentastomids have already been registered (Ribeiro et al., 2012a).

\section{Material and Methods}

The collection of specimens occurred in the region of Araripe, Ceará, in three different physiognomies of the Araripe plateau: Caatinga, Rainforest and Savanna. The Caatinga area studied is located in the municipality of Várzea Alegre, Ceará, Brazil (0652'20”S, 39¹3'03”W; $304 \mathrm{~m}$ altitude), the Savanna environment, at the top of Araripe Plateau in the city of Barbalha, Ceará, Brazil (7²1'55'S, 39²6'26'W; 913 m altitude) and the Rainforest environment located on the slope of the Araripe Plateau, Barbalha (7²1'56'S, 39¹9'42'”W; 760 m altitude).
A total of 90 groups of pitfall traps were installed ( 30 in each environment), each consisting of four buckets of 30 liters (totaling 360 buckets) buried in the ground to the edge, and interconnected by a fence guide, in an array of "Y" with a bucket at the center, and three buckets at each end fence guide. Active collections were also made in the search for lizards, using an air gun (4 mm caliber) and slingshot. Each environment was individually studied for 30 days - 15 days in the dry season and 15 days in the rainy season - totaling 90 days sampling with traps and active searches.

The lizards were sacrificed with Lidocaine injection, and then were weighed with a precision (0.01) balance (SHIMADZU-BL3200H), and snout-vent length (SVL) was measured (accuracy $0.01 \mathrm{~mm}$ ) and fixed in $10 \%$ formalin; and after 48 hours, they were washed in flowing water and preserved in $70 \%$ alcohol. The organs of the lizards were analyzed, and sexes were identified from the analysis of their gonads. Specimens are deposited in the Herpetological Collection of the Universidade Federal da Paraíba (CHUFPB), and the Universidade Regional do Cariri (CH-URCA).

The respiratory tracts of lizards were removed for analysis of parasites. The parasites were preserved in 70\% alcohol. To identify pentastomids, the specimens were mounted on slides in permanent Hoyer, and then analyzed under a light microscope. The parasitological terms follow Bush et al. (1997). Pentastomids were identified based on the dimensions of hooks and copulatory spicules of males (Almeida et al., 2008a; Ali et al., 1985).

\section{Results and Discussion}

A total of 45 lizards, Ameiva ameiva species were collected (17 = Caatinga; $26=$ Savanna; 2 = Rainforest environment $)$. Fifteen were adult males $(160.67 \pm 8.32 \mathrm{~mm} \mathrm{SVL}), 14$ were adult females ( $133 \pm 15.31 \mathrm{~mm} \mathrm{SVL})$ and 13 were juveniles $(47.40 \pm 19.42 \mathrm{~mm}$ SVL). Only one specimen (collected in rainforest environment) was parasitized (nine specimens) by Raillietiella mottae (prevalence of $2.22 \%, 1 / 45$ considering all the lizards collected in the region and prevalence of 50\%, considering only rainforest environment). Ameiva ameiva is a new host for Pentastomids.

The highest rates of infection prevalence for pentastomid Raillietiella, registered for lizards were found in samples of at least 15 lizards, where only geckos had prevalence higher than 14\% (Anjos et al., 2007; Almeida et al., 2008c; Sousa et al., 2010). A low prevalence of infection for pentastomids as identified in A. ameiva (considering the entire region studied), has also been identified in other lizards: M. agilis (Scincidae) =3.6-9.0\% (Vrcibradic et al., 2002); . hispidus (Tropiduridae) $=1.0 \%$ (Almeida et al., 2008c); H. mabouia (Gekkonidae $)=9.1 \%$ (Anjos et al., 2008); Phyllopezus pollicaris $=3.63 \%$ (Brito et al., 2014); Cnemidophorus abaetensis (6.0\%) (Dias et al., 2005), C. ocellifer (2.5\%) (Dias et al., 2005). The lizard M. arajara was also identified as host Pentastomida Raillietiella mottae with a low prevalence (1.6\%) (Ribeiro et al., 2012a) in 
the same area where we found the infected specimen of A. ameiva.

The Teiidae family has only two records of the species Raillietiella aff. furcocerca infecting C. abaetensis and C. ocellifer with intensity of infection comparatively low (1) and (4.5), respectively (Dias et al., 2005). In the study by Brito et al. (2014), A. ameiva was sampled in three different populations of Caatinga vegetation, and there was no registered pentastomid infection for this species, which may indicate the presence of Pentastomida in Teiidae lizards, occur accidentally or occasionally without causing apparent damage to the tissues of the infected organ.

\section{Acknowledgements}

This study was supported by research grants from Fundação Cearense de Apoio ao Desenvolvimento Científico e Tecnológico (BPI - FUNCAP), Conselho Nacional de Desenvolvimento Científico e Tecnológico (CNPq) (PQ-302429/2015-8), Coordenação de Aperfeiçoamento de Pessoal de Nível Superior (CAPES). A license was provided by Instituto Brasileiro do Meio Ambiente e dos Recursos Naturais Renováveis (ICMBio/SISBio: 29838-1, 29838-2). The Proofreading group (PRS) reviews our use of English.

\section{References}

ALI, J.H., RILEY, J. and SELF, J.T., 1985. A review of the taxonomy and systematics of the pentastomids genus Raillietiella Sambon, 1910 with a description of a new species. Systematic Parasitology, vol. 7, no. 2, pp. 111-123. http://dx.doi.org/10.1007/ BF00009814.

ALMEIDA, W.O., FREIRE, E.M.X. and LOPES, S.G., 2008a. A new species of Pentastomida infecting Tropidurus hispidus (Squamata: Tropiduridae) from caatinga in Northeastern Brazil. Brazilian Journal of Biology $=$ Revista Brasileira de Biologia, vol. 68, no. 1, pp. 199-203. http://dx.doi.org/10.1590/S151969842008000100029. PMid:18470398.

ALMEIDA, W.O., SANTANA, G.G., VIEIRA, W.L.S., WANDERLEY, I.C., FREIRE, E.M.X. and VASCONCELLOS, A., 2008b. Pentastomid, Raillietiella mottae Almeida, Freire and Lopes, 2008, infecting lizards in an area of caatinga, northeast, Brazil. Brazilian Journal of Biology $=$ Revista Brasileira de Biologia, vol. 68, no. 2, pp. 203-207. http://dx.doi.org/10.1590/ S1519-69842008000200028.

ALMEIDA, W.O., SANTANA, G.G., VIEIRA, W.L.S., WANDERLEY, I.C., FREIRE, E.M.X. and VASCONCELLOS, A., 2008c. Pentastomid, Raillietiella mottae Almeida, Freire and Lopes, 2008, infecting lizards in an area of caatinga, northeast, Brazil. Brazilian Journal of Biology $=$ Revista Brasileira de Biologia, vol. 68, no. 2, pp. 427-431. http://dx.doi.org/10.1590/ S1519-69842008000200028. PMid:18660975.

ALMEIDA, W.O., SANTANA, G.G., VIEIRA, W.L.S. and WANDERLEY, I., 2008d. Infection rates of pentastomids on lizards in urban habitats from Brazilian Northeast. Brazilian Journal of Biology $=$ Revista Brasileira de Biologia, vol. 68, no. 4, pp. 885-888. http://dx.doi.org/10.1590/S1519-69842008000400026. PMid:19197509.
ALMEIDA, W.O., SANTANA, G.G., VIEIRA, W.L.S., WANDERLEY, I.C. and RIBEIRO, S.C., 2009. Rates of pulmonary infection by pentastomids in lizards species from a restinga habitat in northeastern Brazil. Brazilian Journal of Biology = Revista Brasileira de Biologia, vol. 69, no. 1, pp. 197-200. http://dx.doi. org/10.1590/S1519-69842009000100026. PMid:19347165.

ANJOS, L.A., ALMEIDA, W.O., VASCONCELLOS, A., FREIRE, E.M.X. and ROCHA, C.F.D., 2007. The alien and native pentastomids fauna of an exotic lizard population from Brazilian Northeast. Parasitology Research, vol. 101, no. 3, pp. 627-628. http://dx.doi.org/10.1007/s00436-007-0526-7. PMid:17384963.

ANJOS, L.A., ALMEIDA, W.O., VASCONCELLOS, A., FREIRE, E.M.X. and ROCHA, C.F.D., 2008. Pentastomids infecting an invader lizard, Hemidactylus mabouia (Gekkonidae) in northeastern Brazil. Brazilian Journal of Biology $=$ Revista Brasileira de Biologia, vol. 68, no. 3, pp. 611-615. http://dx.doi. org/10.1590/S1519-69842008000300019. PMid:18833483.

BRITO, S.V., CORSO, G., ALMEIDA, A.M., FERREIRA, F.S., ALMEIDA, W.O., ANJOS, L.A., MESQUITA, D.O. and VASCONCELLOS, A., 2014. Phylogeny and micro-habitats utilized by lizards determine the composition of their endoparasites in the semiarid Caatinga of Northeast Brazil. Parasitology Research, vol. 113, no. 11, pp. 3963-3972. http://dx.doi.org/10.1007/s00436014-4061-z. PMid:25096534.

BUSH, A.O., LAFFERTY, K.D., LOTZ, J.M. and SHOSTAK, A.W., 1997. Parasitology meets ecology on its own terms: Margolis et al. revisited. The Journal of Parasitology, vol. 83, no. 4, pp. 575-583. http://dx.doi.org/10.2307/3284227. PMid:9267395.

CHRISTOFFERSEN, M.L. and ASSIS, J.E., 2013. A systematic monograph of the Recent Pentastomida, with a compilation of their hosts. Zoölogische Mededeelingen, vol. 87, pp. 1-206.

DIAS, E.J.R., VRCIBRADIC, D. and ROCHA, C.F.D., 2005. Endoparasites infecting two species of whiptail lizards (Cnemidophorus abaetensis and Cocellifer; Teiidae) in a restinga habitat of northeastern Brazil. The Herpetological Journal, vol. 15, no. 2, pp. 133-137.

KLINGENBERG, R.J., 1993. Understanding reptile parasites: a basic manual for herpetoculturists \& veterinarians, Lakeside: Advanced Vivarium Systems.

MARCOGLIESE, D.J., 2004. Parasites: small players with crucial roles in the ecological theater. EcoHealth, vol. 1, no. 2, pp. 151-164. http://dx.doi.org/10.1007/s10393-004-0028-3.

MOTTA, C.S. and GOMES, D.C., 1968. Sobre um novo gênero e uma nova espécie de Cephalobaenidae (Linguatulida, Cephalobaeniformia). Atas da Sociedade de Biologia do Rio de Janeiro, vol. 12, no. 1, pp. 7-9.

PHILLIPS, B.L., KELEHEAR, C., PIZZATTO, L., BROWN, G.P., BARTON, D. and SHINE, R., 2010. Parasites and pathogens lag behind their host during periods of host range advance. Ecology, vol. 91, no. 3, pp. 872-881. http://dx.doi.org/10.1890/09-0530.1. PMid:20426344

RIBEIRO, S.C., FERREIRA, F.S., BRITO, S.V., TELES, D.A., ÁVILA, R.W., ALMEIDA, W.O., ANJOS, L.A. and GUARNIERI, M.C., 2012a. Pulmonary infection in two sympatric lizards, Mabuya arajara (Scincidae) and Anolis brasiliensis (Polychrotidae) from a cloud forest in Chapada do Araripe, Ceará, Northeastern Brazil. Brazilian Journal of Biology $=$ Revista Brasileira de Biologia, vol. 72, no. 4, pp. 929-933. http://dx.doi.org/10.1590/S151969842012000500021. PMid:23295524. 
RIBEIRO, S.C., ROBERTO, I.J., SALES, D.L., ÁVILA, R.W. and ALMEIDA, W.O., 2012b. Amphibians and reptiles from Araripe Bioregion, Northeastern Brazil. Salamandra, vol. 48, pp. 133-146.

RILEY, J., 1986. The biology of pentastomids. Advances in Parasitology, vol. 25, pp. 45-128. http://dx.doi.org/10.1016/ S0065-308X(08)60342-5. PMid:3535437.

ROCHA, C.F.D., VRCIBRADIC, D. and ARAÚJO, A.F.B., 2000. Ecofisiologia de répteis de restingas brasileiras. In: F.A. ESTEVES and L.D. LACERDA, eds. Ecologia de restingas e lagoas costeiras. Macaé: NUPEM, UFRJ. pp. 117-149.

SOUSA, J.G.G., BRITO, S.V., ÁVILA, R.W., TELES, D.A., ARAUJO-FILHO, J.A., TEIXEIRA, A.A.M., ANJOS, L.A. and ALMEIDA, W.O., 2014. Helminths and Pentastomida of two synanthropic gecko lizards, Hemidactylus mabouia and Phyllopezus pollicaris, in an urban area in Northeastern Brazil. Brazilian Journal of Biology = Revista Brasileira de Biologia, vol. 74, no. 4, pp. 943-948. http://dx.doi.org/10.1590/15196984.01413. PMid:25627607.
SOUSA, J.G.G., RIBEIRO, S.C., ROBERTO, I.J., TELES, D. and ALMEIDA, W., 2010. Ocorrência de pentastomídeos (Metameria: Ecdysozoa) no lagarto Phyllopezus pollicaris (Spix, 1825). Cadernos de Cultura e Ciência, vol. 2, no. 2, pp. 64-71.

VITT, L.J. and COLLI, G.R., 1994. Geographical ecology of a Neotropical lizard: Ameiva ameiva (Teiidae) in Brazil. Canadian Journal of Zoology, vol. 72, no. 11, pp. 1986-2008. http://dx.doi. org/10.1139/z94-271.

VITT, L.J., 1995. The ecology of tropical lizards in the caatinga of Northeast Brazil. Occasional Papers of the Oklahoma Museum of Natural History, vol. 1, pp. 1-29.

VRCIBRADIC, D., ROCHA, C.F.D., BURSEY, C.D. and VICENTE, J.J., 2002. Helminth communities of two sympatric skinks (Mabuya agilis and Mabuya macrorhyncha) from two 'restinga' habitats in southeastern Brazil. Journal of Helminthology, vol. 76, no. 4, pp. 355-361. http://dx.doi.org/10.1079/JOH2002134. PMid:12498642. 